УДК 502.14

DOI https:/ / doi.org/10.32837/yuv.v0i2.1735

\title{
А. Головко,
}

здобувач кафедри теорії держави та права

Національної академії внутрішніх справ

\section{МЕТОДОЛОГІЧНІ ПІДХОДИ ДО ДОСЛІДЖЕННЯ ПРИРОДООХОРОННОї ДІЯЛЬНОСТІ}

Реформування екологічної системи суспільства, підвищення рівня ефективності здійснення охорони навколишнього середовища, зміна пріоритетів у природоохоронній діяльності державних органів і громадських організацій можуть призвести до очікуваного результату лише за умови їх належного наукового забезпечення. Соціальна цінність та ефективність доктринального опрацювання теоретико-правових засад природоохоронної діяльності значною мірою визначаються іх методологічною обгрунтованістю. Як слушно стверджує В.В. Костицький, 3 огляду на перспективи, зумовлені глобалізаційними процесами, європейськими та євроатлантичними прагненнями України, проблема створення цілісної системи управління охороною довкілля вимагає якісно нових підходів, визначення іï основних підсистем, які мають базуватися на принципово нових концептуальних і методологічних засадах [1, с. 2].

Адже сучасні глобалізаційні процеси, що об’єктивно стимулюються прогресуванням суспільної «відкритості» та справляють дедалі відчутніший вплив на характер усіх компонентів правової реальності, відзначаються досить суперечливим характером. Окрім безперечних переваг у плані сприяння інтеграції зусиль, спрямованих на вирішення «транскордонних» проблем, вони несуть у собі низку загроз щодо геоекономічної та геополітичної пропорційності розвитку світової системи, збереження й підтримання в ній належного демографічного та екологічного балансу тощо. Тому парадигмальні зміни в поглядах на зміст і цільові орієнтири природоохоронної діяльності мають оцінюватися з погляду їхньої зорієнтованості на розширення можливостей стосовно протидії негативним ефектам глобалізації та на забезпечення дієвих механізмів використання ії конструктивного потенціалу [2, с. 338].

Водночас непослідовність і недосконалість правового регулювання природоохоронної діяльності в Україні $€$ закономірним наслідком відсутності чітко окреслених і науково виважених методологічних засад осмислення окремих аспектів охорони навколишнього середовища. Разом із тим зміни структури та характеру суспільних відносин у нашій державі, що пов'язані 3 реалізацією гарантованого Основним Законом України пріоритету прав і свобод людини, зумовлюють необхідність вироблення якісно нового методологічного інструментарію для гармонізації суспільних відносин в екологічній сфері.

У зв'язку із цим особливої важливості набуває виокремлення і характеристика ключових методологічних (дослідницьких) підходів до дослідження природоохоронної діяльності, що становить мету цієї наукової розвідки. Для іï успішного досягнення передбачається вирішити такі завдання: по-перше, окреслити наявний стан і тенденції розвитку методології сучасного правознавства; по-друге, проаналізувати структуру методології конкретнонаукового дослідження та місце в ній дослідниць- 
ких підходів; по-третє, охарактеризувати пізнавальний потенціал ключових методологічних підходів до осмислення теоретико-правових засад природоохооронної діяльності.

Нинішній етап розвитку юриспруденціі, як і науки взагалі, певною мірою можна було б назвати етапом пошуку ї методологічних засад. Розроблення методології визнано пріоритетним напрямом наукових досліджень у юридичній науці взагалі та ї̈ окремих галузях. Так, провідні міжнародні наукові конференції рекомендують уважати розроблення методологічних проблем правознавства одним із найважливіших завдань юридичної науки. Зважений методологічний підхід орієнтує науковців на пошук принципово нових шляхів вирішення теоретичних і практичних проблем, результати якого були б початком майбутніх теоретичних досліджень і містили їх методологію [3, с. 7]. Проблема методології є неминучою для будь-якої науки. I це зрозуміло, адже плідність наукового пізнання, ступінь i глибина його проникнення у сутність досліджуваних явищ i процесів, а зрештою - приріст наукових знань значною, а нерідко й вирішальною мірою залежать від методологічного інструментарію, що використовується дослідниками. Ця проблема набула для пострадянського правознавства особливої актуальності. Панування довгі роки моністичного матеріалістичного підходу до вивчення правових явищ, негативне ставлення до всіх інших доктрин і теорій, побудованих на відмінних від матеріалізму світоглядних позиціях, перешкоджали використанню здобутків європейської і світової правової теорії і правової культури, збіднювали уявлення про право та його місце в системі засобів соціального регулювання і способів світосприйняття. Тому невипадково увага до проблем методології у вітчизняному, як і пострадянському загалом, правознавстві в останні два десятиліття помітно зросла [4, с. 22].

У філософсько-довідковій літературі під методологією розуміється складник сучасного наукового пізнання, сутність якого розкривається в кількох значеннях: 1) учення про методи наукового пізнання; 2) метатеорія науки, завданням якої $€$ реконструкція науки з метою виявлення особливостей будови та оптимізації іi функціонування; 3) рівень теоретичного самоусвідомлення науки [5, с. 98]. В енциклопедичній праці із загальної теорії держави та права методологія визначається як сукупність методів (прийомів, способів і засобів), що використовуються у процесі наукового пізнання та здійснення практичної діяльності. Це система науково обгрунтованих підходів, положень і процедур, які у поєднанні становлять єдину методологічну основу, застосовуються під час наукового пізнання та здійснення практичної діяльності, містять єдині правила щодо порядку й умов застосування пізнавального інструментарію. При цьому методологія юридичної науки - це система методів (принципи, правила, прийоми, способи і засоби), які використовуються всіма юридичними науками в ході наукового пізнання, та містить правила їх використання [6, с. 154], а методологія теорії держави та права - це система методів (правил, прийомів, способів, засобів), що використовуються у процесі наукового пізнання та дослідження окремих аспектів функціонування, діяльності, розвитку державно-правових явищ. Методологія теорії держави та права визначає взаємодію методів, забезпечує єдині підходи до вивчення предмета; забезпечує науковість пізнання; характеризує наукову діяльність як багатоаспектну, що здійснюється у межах чітко визначених етапів; забезпечує дослідження державно-правових категорій і характеризує ї призначення в суспільстві [6, с. 155].

Своєю чергою, М.С. Кельман відзначає, що методологією сучасного правознавства (юридичної науки) є вчення про структуру, логічну організацію, принципи, методи, засоби та форми діяльності дослідника у процесі пізнання ним досліджуваних державно-правових 
явищ. Методологія юридичної науки забезпечує як наукове пізнання, так i наукову діяльність учених-юристів. Вона $є$ формою самопізнання та самосвідомості юриспруденції. Методологія правознавства повинна мати чітку структуру (вертикальну та горизонтальну), що охоплює загальні компоненти лише в різних відносинах між ними: домінуючий світогляд, тип наукового мислення, філософські й інші підстави, загальнонаукові та спеціальнонаукові парадигми, методологічні підходи, теорії та інші наукові знання, потенційно можливі й використовувані методи. Це - важлива передумова формування ефективної системи правового регулювання [7, с. 10].

Методологія правових досліджень i уявлення вчених про іiі потенціал сформувалися історично під вПливом надбань філософії та науки про метод як шлях пізнання та розуміння явищ об'єктивного світу. Аналіз праць із методологічних проблем юридичної науки свідчить про наявність надзвичайно широкого спектра точок зору щодо розуміння сутності методології в історичному (І.А. Безклубий, М.А. Дамірлі, О.В. Меленко), філософському (А.А. Козловський, М.В. Костицький, Л.В. Петрова, Б.Б. Руденко), теоретичному (С.Д. Гусарєв, М.С. Кельман, М.I. Козюбра, П.М. Рабінович, О.Ф. Скакун, О.Д. Тихомиров) і галузевому (В.С. Вишновецька, П.С. Пацурківський, В.Л. Федоренко) вимірах. При цьому протягом XX ст. методологія від класичної парадигми, побудованої на принципах об'єктивності, істинності, монізму, детермінізму і сцієнтизму, через некласичну (з їі свободою вибору і суб'єктивністю) перейшла до постнекласичного (постмодерністського) типу, який характеризується інтерсуб'єктивністю, додатковістю, плюралізмом і міждисциплінарністю. В основі постнекласичної парадигми лежать переконання про неможливість установлення об'єктивно істинного знання про право, оскільки воно не є частиною об'єктивної реальності.
I право, і знання про нього є сферами інтерпретацій, жодна 3 яких не може претендувати на істинність. Відповідно, саме правове пізнання стає елементом правової реальності, фактором іï функціонування [8, с. 42]. Важливою тенденцією розвитку сучасного правознавства $€$ відхід від заідеологізованості, актуалізація людиноцентричних, «олюднених» наукових досліджень у сфері як приватного, так і публічного права. Новітне правознавство розвивається зі сприйняттям і засвоєнням загальноцивілізаційних та європейських цінностей, 3 яких визначальні - невідчужувані права і свободи людини, зокрема екологічні, справедливість, індивідуальність, гуманізм, рівність, верховенство права [7, с. 23].

Структурно методологія має кілька рівнів, основними 3 яких є такі: діалектико-світоглядний - визначає головні вектори та загальні принципи пізнання у цілому (вищий рівень); загальнонауковий (міждисциплінарний) - використовується під час пізнання особливої групи однотипних об'єктів (середній рівень); конкретно науковий - застосовується у процесі пізнання специфіки окремого об'єкта (нижчий рівень); перехідний від пізнавально-теоретичної до практично-перетворюючої діяльності - розкриває загальні шляхи та форми впровадження результатів наукових досліджень у практику. Між цими рівнями методології існують органічний зв'язок, залежність, підпорядкованість і взаємопроникнення [9, с. 86]. Відповідно до позиції С.Д. Гусарєва та О.Д. Тихомирова, методологія сучасного правознавства являє собою багатопланове утворення, яким охоплюються: 1) проблеми структури наукового знання взагалі та наукових правових теорій зокрема; 2) закони виникнення, функціонування правових теорій; 3) поняттєво-категоріальний апарат юридичної науки та їі окремих дисциплін; 4) структура та операційний склад методів юридичної науки; 5) аналіз іï мови, формальних і формалізованих методів дослідження (методики 
і процедури дослідницької діяльності), типології систем наукового правового знання. Таким чином, зміст методології сучасного правознавства становить система принципів та способів організації, побудови і здійснення теоретико-пізнавальної юридичної діяльності в галузі дослідження державно-правової дійсності, а також учення про цю систему [10, с. 63].

Трансформуючи окреслені вище судження відносно предмета і завдань наукового пошуку, доречно виокремити такі складники методології дослідження теоретико-правових засад природоохоронної діяльності: по-перше, світоглядні, філософські, наукознавчі, соціологічні та теоретичні основи; по-друге, принципи наукового пізнання; по-третє, методологічні (дослідницькі) підходи; по-четверте, основні наукові методи вивчення предмета та побудови відповідних наукових знань. Такий підхід до опису структури методології осмислення природоохоронної діяльності не заперечує доцільність, можливість і необхідність інших, а, навпаки, забезпечує їх збагачення i взаємодоповнення, цілісність ї сприйняття, оскільки побудова різноманітних класифікацій або виокремлення різноманітних структур методології конкретної наукової розвідки не є самоціллю, а зумовлена необхідністю встановлення взаємозв'язків між їі компонентами, що $€$ необхідним для правильного вибору «арсеналу», «інструментарію» методологічних принципів, прийомів, правил, засобів теоретико-правових досліджень відповідно до сутності природоохоронної діяльності й особливостей наукового знання із цієї проблематики.

Ступінь достовірності пізнавальної діяльності визначається як відповідність іï результатів «реальному стану речей», що залежить від вибору і використання правильного шляху та найбільш адекватних засобів наукового дослідження. Саме тому питання методологічного забезпечення $€$ першочерговим для теоретичного осмислення в будь-якій предметній сфері. Лише за умови озброєності сучасною методологією вітчизняна юридична наука зможе виконати поставлене перед нею завдання 3 удосконалення правового регулювання природоохоронної діяльності в Україні в умовах євроінтеграції.

Звідси слідує, що методологічні підходи є визначальною за евристичним потенціалом складовою частиною (рівнем) методології дослідження теоретико-правових засад природоохоронної діяльності. Якщо юридична наука вивчає об'єкт, яким виступають держава і право, то методологія юридичної науки звернена до взаємодії юридичної науки з їі об'єктом. Цю спрямованість методології юриспруденції відображають, насамперед, методологічні підходи, що становлять основу сучасної юридичної методології [11, с. 37]. Методологічні (дослідницькі) підходи безпосередньо залежать від наукових парадигм і здебільшого $є$ результатом їх використання, до того ж цей вплив здійснюється не лише за рахунок ідеалів, норм, правил досліджень, що містяться в парадигмі, а й їх предметних положень. Концептуальний підхід у системі методології правового пізнання - це загальна стратегія дослідження, спрямована на опис образу права з позиції деякої наперед сформованої, фундаментальної ідеї або аксіоматичної засади. Використання концептуальних підходів $€$ способом залучення позаправових ідей і концепцій, у тому числі найширшого, світоглядного рівня [12, с. 461]. Сучасне правознавство вже давно не схоже на «юриспруденцію понять» XIX ст., його погляд на правові феномени не обмежується лише формально-логічними, поняттєвими формами. Таке розширення предметної сфери, поява нових «онтологій права» стали можливими на основі використання нових пізнавальних підходів. Методологічний підхід $€$ одним із головних компонентів парадигми та розглядається як своєрідний «ансамбль» взаємозалежних наукових методів. Методологічний підхід містить у собі різноманітні взаємозалежні 
методи, певним чином пов'язані між собою, серед яких один або декілька $€$ ключовими, а всі інші підпорядковані їм, залежні від них, мають допоміжний характер. Поняття «підхід» є загальноприйнятим у сучасній соціальній науці із середини 1960-х років, одержавши досить чіткі визначення як певного «способу організації пізнавального процесу в конкретній науці, що фіксує не лише інструментальну сторону пізнання, але й світоглядну, загальнотеоретичну» [13, с. 227]. У цьому контексті заслуговують на увагу міркування А.О. Фальковського про те, що підхід стосовно методу $є$ більш високим рівнем методології. В основі підходів лежить концептуальна ідея, що безпосередньо визначає спрямованість і впливає на інтерпретацію результатів дослідження. Підхід $є$ формою органічного поєднання світоглядно-філософської спрямованості 3 методичним інструментарієм, який використовується в певній галузі дослідження. Сутність підходу не вичерпується сукупністю методів, а повинна включати також компоненти більш загального порядку (ідеї) та окремого, суб'єктивного (оцінки). Підходом у методології юриспруденції можна вважати загальну спрямованість дослідження, зумовлену певною фундаментальною ідеєю, крізь яку проходить процес осягнення права. Вибір підходу визначає відбір методів дослідження, а також інтерпретацію отриманих результатів крізь призму певної концептуальної ідеї [14, с. 11].

Провідну пізнавальну роль у комплексному дослідженні теоретико-правових засад природоохоронної діяльності відіграє діяльнісний підхід. На переконання С.Д. Гусарєва та Є.В. Білозьорова, діяльнісний підхід у правознавстві - це гармонійна сукупність установок, прийомів, ансамбль методів, серед яких метод діяльності вважається провідним, а інші стосовно нього виконують обслуговуючу роль. Цей підхід дає змогу зосередити увагу дослідника не тільки на проблемі власне діяльності, а й на інших явищах, у співвідношенні або взаємодії з якими знаходиться людська діяльність. Слід констатувати досить широкі можливості застосування категорії «діяльність» як принцип або метод пізнання у сфері правових досліджень. Це можуть бути наукові розвідки, присвячені вивченню окремо взятої особистості, колективу осіб, аспектів взаємодії державних підприємств та установ, а також стосовно здійснення правотворчості, проблем реалізації права, забезпечення природоохоронної діяльності тощо. Головною рисою методу діяльності $€$ можливість пізнання явища правової дійсності крізь призму існування такого чинника, як людська діяльність. На відміну від методу, діяльнісний підхід дає змогу ставити та вирішувати більш складні науково-пізнавальні завдання, що підтверджується розширенням його гносеологічного інструментарію [15, с. 128].

Серед низки дослідницьких підходів до вивчення сутності природоохоронної діяльності доречно виокремити системний. Найчастіше останній надає можливість осягнути взаємодію держави та права як комплексний процес у всіх його проявах. Такий підхід припускає розгляд державних і правових явищ як цілісних сукупностей різноманітних елементів (складових частин), що взаємодіють між собою і навколишнім середовищем [16, с. 76]. Як стверджує Л.В. Жарова, система природоохоронної діяльності $є$ продуктом людської діяльності (тобто штучною), динамічною та зазвичай постійною системою, хоча ї окремі елементи чи підсистеми можуть мати тимчасовий характер. Система природоохоронної діяльності $€$ багаторівневою і складною відкритою системою (тобто залежною від зовнішнього середовища), яка має параметри входу, виходу і складний зв'язок між елементами (підсистемами), котрі є iï складниками [17, с. 75]. Структурно-динамічна теорія повинна стати основою для дослідження складної, штучної, динамічної і зазвичай постійної системи природоохоронної діяльності, якій притаманні всі властивості 
системи та яка перебуває в постійному розвитку і прагне до біфуркаційної сталості $[17$, с. 81$]$.

У ході вивчення міжнародного та європейського досвіду правового регулювання природоохоронної діяльності актуальності набуває компаративний підхід. Це один із сучасних методологічних підходів юридичної науки, який базується на порівняльно-правовому методі, але не зводиться лише до нього, має міждисциплінарне значення поряд із такими підходами, як соціологічний, історичний, системний, функціональний та інші, і спрямований на дослідження «не одного» об'єкта. Визнання плюралізму та рівноправності культур, їх взаємодії на основі діалогу, необхідності розвитку не лише загальнолюдського, а й регіонального, національно самобутнього у світовому просторі потребує подальшого вивчення природоохоронної діяльності у «форматі» співвідношення загального, особливого, одиничного та унікального, що відповідає саме порівняльно-правовому чи компаративістському їх осмисленню [18, с. 349].

Одним із важливих гносеологічних засобів опрацювання природоохоронної діяльності $€$ антропологічний підхід, тобто засновані на висновках певних видів антропології світоглядні ідеї про природу та сутність людини, які визначають особливості виявлення, добору і систематизаціі науковцем досліджуваних фактів, а також ї інтерпретаціі та оцінки. Основу антропологічного підходу становить осмислення правового буття людини. Цей підхід виходить із того, що біологічна незахищеність людини породжує потребу у природоохоронній діяльності у сфері забезпечення екологічних прав і обов'язків людини. Антропологічний підхід ставить людину як «міру всіх речей» у центр здійснення природоохоронної діяльності, вивчає іï роль у формуванні та вдосконаленні цієї діяльності, життєдіяльність усередині неї, взаємний вплив (включаючи деструктивний) людини та навколишнього середовища.
Викликає науковий інтерес аксіологічний (ціннісний) підхід як своєрідний спосіб пізнання сутності природоохоронної діяльності. Аксіологічний підхід $€$ інтегруючим, він імпліцитно присутній у кожному з концептуальних дослідницьких підходів, за його допомогою визначається: по-перше, цінність природоохоронної діяльності як різновиду соціальної діяльності; по-друге, здатність природоохоронної діяльності втілювати в життя певні цінності; по-третє, ціннісне наповнення змісту природоохоронної діяльності в умовах розбудови в Україні екологічної держави за участю громадянського суспільства. Ціннісний (аксіологічний) підхід у методології юриспруденції це загальна стратегія дослідження, що визначає, зокрема, розгляд природоохоронної діяльності крізь призму їі відповідності певним цінностям, які можуть забезпечуватися цією діяльністю та бути ії основою [14, с. 12].

Вельми цінним $є$ використання потребового підходу під час опрацювання теоретико-правових засад природоохоронної діяльності. За твердженням П.М. Рабіновича, потребовий підхід - це методологічне підгрунтя сутнісного праворозуміння, ключ до виявлення соціальної сутності праволюдинних явищ. В основі цього підходу лежить аксіоматична ідея про те, що соціальна природа, сутність явищ, у тому числі природоохоронної діяльності, - це їх здатність слугувати засобом, інструментом задоволення потреб, зокрема екологічних, людини, соціальних спільнот, суспільства у цілому [19, с. 19].

Отже, на основі проаналізованого вище є всі підстави стверджувати, що важливим етапом наукового пізнання $€$ правильний та обгрунтований підбір методологічного інструментарію. Юридична наука отримує об'єктивні знання про суспільні явища та процеси тоді, коли має належну методологічну основу. При цьому вітчизняному загальнотеоретичному правознавству властива наявність не окремо взятого 
дослідницького підходу до осмислення проблематики теоретико-правових засад природоохоронної діяльності, а їх сукупність. Адже лише плюралізм методологічних підходів дає змогу здійснити аксіологічний і потребовий підходи.

У статті автор характеризуе ключові методологічні (дослідницькі) підходи до дослідження природоохоронної діяльності, окреслюе наявний стан $i$ тенденції розвитку методологіі сучасного правознавства. Зазначено, що сучасна юриспрудениія розвивається зі сприйняттям та засвоєнням загальнолюдських та європейських иінностей, визначальними серед яких є права та свободи людини, включаючи екологічні права, справедливість, індивідуальність, гуманізм, рівність та верховенство права. Автор аналізуе структуру сучасної методологї юридичної науки та з'ясовує місце дослідницьких підходів піә час дослідження суспільно-правових явищ. Методологічні (дослідницькі) підходи безпосередньо залежать від наукових парадигм $і$ здебільшого є результатом іх використання; крім того, ией вплив здійснюється не лише за допомогою ідеалів, норм, правил, а й ї предметних положень. у дослідженні зазначено, що загальнотеоретична юриспруденція характеризується наявністю не єдиного дослідницького підходу до розуміння проблем теоретико-правових приничипів охорони навколишнього середовищца, а їх сукупності. Автор підсумовує, що плюралізм методологічних підходів дає змогу всебічно вивчити концепцію, особливості, принципи, функиіі та механізм охорони навколищнього природного середовища в Україні та визначити аспекти вдосконалення правового регулювання природоохоронної діяльності в контексті європейської та євроатлантичної інтеграції.

Ключові слова: природоохоронна діяльність, теоретико-правові засади природоохоронної діяльності, методологія, методологія правознавства, методологічні підходи.

Holovko A. Methodological approaches to the study of environmental activities

In the article the author characterizes the key methodological (research) approaches to the study of environmental activities. Outlines the current state and trends in the methodology of modern jurisprudence. It is established that modern jurisprudence develops with the perception and assimilation of universal and European values, of which the defining - inalienable human rights and freedoms, including environmental, justice, individuality, humanism, equality, rule of law. Analyzes the structure of the methodology of specific research and the place of research approaches in it. Methodological approaches is crucial for the potential of heuristic component (level) research methodology of theoretical and legal foundations of environmental activities. Methodological (research) approaches directly depend on scientific paradigms and are mostly the result of their use, in addition, this influence is carried out not only through the ideals, norms, rules of research contained in the paradigm, but also their subject provisions. Reveals the cognitive potential of key methodological approaches to understanding the theoretical and legal foundations of environmental activities. The key research approaches to the study of theoretical and legal principles of environmental protection include activity (leading), systemic, comparative, anthropological, axiological and demanding. At the same time, domestic general theoretical jurisprudence is characterized by the presence of not a single research approach to understanding the problems of theoretical and legal principles of environmental protection, but their totality. After all, only the pluralism of methodological approaches allows 


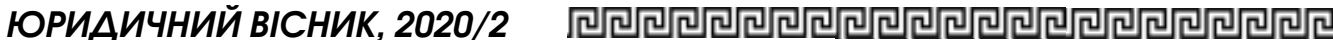

for a comprehensive study of the concept, features, principles, functions and mechanism of environmental protection in Ukraine and identify areas for improving its legal regulation in the context of European and Euro-Atlantic integration.

Key words: environmental activities, theoretical and legal bases of environmental activities, methodology, methodology of jurisprudence, methodological approaches.

\section{Література}

1. Костицький В.В. Економіко-правовий механізм охорони навколишнього природного середовища: теорія та практика: автореф. дис. ... д-ра юрид. наук : 12.00.06. Kü̈, 2004. 52 c.

2. Хірсін А.В. Методологія обтрунтування права: від класики до сучасності : монографія. Київ : IHTЕРСЕРВIC, 2013. $380 \mathrm{c}$.

3. Балинська O.М., Ященко В.А. Методологія сучасного правознавства : посібник / за заг. ред. О.М. Балинської. Львів : ЛьвДУВС, 2018. 372 с

4. Козюбра М. Методологія правознавства і методологія права: співвідношення понять та їх особливості. Право України. 2014. № 1. С. 22-32.

5. Петрушенко В. Тлумачний словник основних філософських термінів. Львів: Львівська політехніка, 2009. 264 с.

6. Мала енииклопедія теорії держави та права / С.Б. Бобровник та ін. ; за ред. проф. Ю.Л. Бошицького. Київ : Кондор-Видавниитво, 2012. 368 с.

7. Кельман М.С. Методологія сучасного правознавства: становлення та основні напрями розвитку : автореф. дис. ... д-ра юрид. наук : 12.00.01. Kü̈в, 2013. 35 c.

8. Кривицький Ю.В. Юридична аргументація: доктринальне розуміння та методологічний потенціал. Філософські та методологічні проблеми права. 2019. № 2(18). С. 36-45.

9. Керимов Д.А. Методология права: предмет, функции, проблемь философии права : монография ; 4-е изд. Москва : СГУ 2008. $521 \mathrm{c}$.

10.Гусарєв С.Д., Тихомиров О.Д. Юридична деонтологія (Основи юридичнӧ діяльності) : навчальний посібник ; 3-є вид. перероб. i доп. Київ: Знання, 2008. 495 c.

11. Оборотов Ю. Аспекти розгортання методології юриспруденції. Право України. 2014. № 1. С. 33-39.

12. Оборотов Ю.М., Горобеиь К.В. Методологія правового пізнання. Велика українська юридична енииклопедія : у $20 \mathrm{~m}$. Харків : Право, 2017. T. 2. С. 460-463.

13. Хрідочкін А.В., Макушев П.В. Методологія сучасного правознавства : навчальний посібник. Дніпро : Гельветика, 2017. $368 \mathrm{c}$

14. Фальковський А.О. Аксіологічний підхід в методології сучасної юриспрудениії : автореф. дис. ... канд. юрид. наук : 12.00.12. Одеса, 2011. 17 c.

15. Гусарєв С.Д., Білозьоров Є.В. Діяльнісний підхід як структурний компонент методології сучасного правознавства. Методологія в праві : монографія. Киї : Грамота, 2017. С. 122-128.

16. Заморська Л.І. Правова нормативність та ї̈ інституціоналізація в Україні : монографія. Одеса : Фенікс, 2013. 304 c.

17. Жарова Л.В. Природоохоронна діяльість: питання теорії та методологї впровадження. Продуктивні сили України. 2009. № 1. C. 73-82.

18. Тихомиров О.Д. Компаративний підхід у правознавстві. Велика українська юридична енциклопедія : у $20 \mathrm{~m}$. Харків : Право, 2017. T. 2. С. 349-354.

19. Рабінович П. Основоположні права людини: соиіально-антропна сутність змістова класифікація. Право України. 2010. № 2. C. 18-23. 